Post-secondary Aboriginal Educational Policy in Ontario: Policy and Practical Implications

\author{
Lorenzo Cherubini
}

Associate Professor and Director

The Tecumseh Centre for Aboriginal Research and Education

Faculty of Education, Brock University

aboriginal policy studies Vol. 2, no. 1, 2012, pp. 42-55

This article can be found at:

http://ejournals.library.ualberta.ca/index.php/aps/article/view/12371

ISSN: $1923-3299$

Article DOI: http://dx.doi.org/10.5663/aps.v2i1.12371

aboriginal policy studies is an online, peer-reviewed and multidisciplinary journal that publishes original, scholarly, and policy-relevant research on issues relevant to Métis, non-status Indians and urban Aboriginal people in Canada. For more information, please contact us at apsjournal@ualberta.ca or visit our website at www.ualberta.ca/nativestudies/aps/.

UNIVERSITY OF ALBERTA

FACULTY OF NATIVE STUDIES
Aboriginal Affairs and

Aboriginal Affairs and
Northern Development Canada

Affaires autochtones et Développement du Nord Canada 


\title{
Post-secondary Aboriginal Educational Policy in Ontario: Policy and Practical Implications
}

\author{
Lorenzo Cherubini \\ Associate Professor and Director \\ The Tecumseh Centre for Aboriginal Research and Education \\ Faculty of Education, Brock University
}

\begin{abstract}
The purpose of this critical discourse analysis of the landmark Ontario Ministry of Training, Colleges, and University educational policy Aboriginal Postsecondary Education and Training Policy Framework (2011) is twofold: first, to draw attention to the problematic language used throughout the policy document in regards to both "closing" achievement gaps and to issues of measurement; second, to attend to the strategic discourse employed in the policy document that situates the Ministry of Training, Colleges, and Universities quite favourably as both a supportive governing body and as a responsible bureaucracy of public money. This critical discourse analysis explores the potentially tense spaces between policy intent and practical implications.
\end{abstract}

\section{Introduction}

Ministries of Education across Canada aim, through public policy, to advance sustainable and improved schooling practices in order to improve student achievement. To some extent, this is true of very recent provincial educational policies related to Aboriginal students and their respective communities, but this has not always been the case. It has been argued by policy advisors that the representation of Aboriginal identities in educational provincial policy initiatives over the last sixty to seventy years has been less plentiful, despite the significant demographic shift of Aboriginal populations and school-aged children from remote to urban-centred and publicly funded mainstream schools (Norris and Clatworthy 2003; Peters 1996, 2003). It seems, historically, that educational polices related to Aboriginal education have neither successfully addressed the challenges of an obviously marginalized Aboriginal student population, nor been characteristically visionary.

Given that Canada prides itself on being a democratic society, it would appear to be unacceptable that any groups or individuals be relegated to the margins of public policy (Grove 2005), particularly the First Peoples of Turtle Island. Canada's Aboriginal peoples were forcefully assimilated during colonization; children were taken from their homes and made to attend residential schools, where they were forced to learn Eurocentric knowledge systems at the peril of the Indigenous knowledge and language traditions they had learned first. Later on, federal day schools were established in lieu of residential schools, but these schools did not represent Aboriginal students' socio-cultural traditions in their pedagogy or practice. In the early 1950s, the Canadian federal government actively encouraged Aboriginal students to attend provincial schools, as per the 1951 revisions to the Indian Act.

aboriginal policy studies, Vol. 2, no. 1, 2012

www.ualberta.ca/nativestudies/aps/

ISSN: 1923-3299 
Quite recently the Ontario Ministry of Education (OME) has taken some decisive measures to enact provincial policy related to Aboriginal education that speaks to Aboriginal epistemologies, community involvement, and student achievement. One example, the Ontario Aboriginal, Métis, and Inuit Policy Education Framework (2007; hereafter Policy Education Framework), has aimed to advance the awareness of all the stakeholders in public education in Ontario, including the Ontario Ministry of Education, school boards, principals, and teachers involved in $\mathrm{K} \neg-12$ education, in terms of creating culturally respectful learning environments for Aboriginal students and their families in publicly funded schools. The objectives of the 2007 Policy Education Framework emerged to some degree from Aboriginal community values, and from commission educators' attempts to learn about and implement culturally-appropriate practices and approaches better suited to Aboriginal students.

In 2011, with the aim of lending consistency to Ontario educational policy, the Ministry of Training, Colleges, and Universities (MTCU) published, in turn, the Aboriginal Postsecondary Education and Training Policy Framework (Postsecondary Framework) to establish a strategic policy context to account for Aboriginal students' transition to post-secondary education and training. In doing so, the MTCU responded positively to literature citing the imperative of assisting secondary school graduates in transitioning to post-secondary programs, schools, and/or pathways (Carnevale and Derochers 2003; Grubb 2002). Supporting disadvantaged students, according to the research, is particularly important (Valentine et al. 2011). The Postsecondary Framework professes the Ontario government's commitment to Aboriginal learners, focuses upon improving Aboriginal student achievement, and centres on closing the educational gaps between Aboriginal and non-Aboriginal students across the province.

\section{Purpose of this Paper}

The purpose of this paper is to provide a discourse analysis of the landmark Ministry of Training, Colleges, and Universities educational policy in Ontario, and a context for the basis of this analysis. The purpose of the discourse analysis is twofold: first, it draws attention to the problematic language inferred throughout the policy document in regards to "closing" achievement gaps and to issues of measurement. Second, the analysis specifically attends to the strategic discourse employed in the policy document that situates the MTCU quite favourably as both a supportive and committed governing body and as a responsible bureaucracy of public money. This examination of public educational policy is located in the historical and contemporary socio-political realities of Aboriginal peoples, and explores the potentially tense spaces between policy intent and practical implications.

Critical discourse analysis lends itself to this examination since it is focused on notions of power stemming from social constructivism (Fairclough 1992; McIntyre, Francis, and Chapman 2012). By interrogating how discourse is formed in policy, the analysis presented here is better able to examine the manner in which language functions and potentially shapes public perception (Fairclough 2003; Smith 2007). Critical discourse analysis is understood, for the purpose of this paper, as a means to bring to light the ways in which language is implicated in the respective Ontario educational policies under discussion (Thompson 1994). 


\section{The Ontario Policy Context}

The Ministry of Training, Colleges, and Universities clearly states its affiliation with Ontario Ministry of Education educational policies, and both the MTCU and the OME identify Aboriginal education "as a key priority" $(2011,3)$. In Ontario, the OME is responsible for publicly funded K-12 education (with the exception of Aboriginal schools, which are under the jurisdiction of the federal government), while the mandate of the MTCU includes publicly assisted universities and community colleges, as well as the various training sectors directly aligned with the workforce. The MTCU's 2011 post-secondary report, Aboriginal Postsecondary Education and Training Policy Framework, is focused on two central challenges, identified within the document as "improving Aboriginal learners' achievements in educational settings, and closing the educational achievement gaps between Aboriginal and non-Aboriginal people" in Ontario (3). To its credit, the Postsecondary Framework declares itself to be "flexible and broad" enough to inform policy and program implementation within the MTCU, and to foster key relationships with Aboriginal leaders, communities, and other stakeholders invested in post-secondary education and training for Aboriginal people (4).

It is important to note that the post-secondary policy under discussion, in many respects, contributes to the principles presented in Ontario's Aboriginal Postsecondary Education and Training Strategy (1991). That policy's mandate was to increase Aboriginal student enrolment in post-secondary education and to improve their graduation rates. The 1991 Strategy also outlined the various funding arrangements for both universities and colleges in order for these institutions to improve programming and support for Aboriginal students.

Important to this notion of fostering relationships are the statements embedded into the Executive Summary of the 2011 Postsecondary Framework that allude to the Ministry of Training, Colleges, and Universities' consultations with Aboriginal governments, community organizations, and others involved with Aboriginal education in the evolution of this policy document $(2011,4-7)$. The Executive Summary identifies the socio-economic and educational gaps that currently exist between Aboriginal and non-Aboriginal peoples across Ontario, as well as the changing demographics that project a significant increase in the Aboriginal population (5-6). Founded upon the principles of accountability, equity, and inclusion; cooperation and shared responsibility; and respect for constitutional and treaty rights, Indigenous knowledge, languages, and cultures, the goals of the Postsecondary Framework are to provide accountable, transparent, responsive, and respectful governance to promote Aboriginal student success and labour market readiness (5-7).

In lieu of the aforementioned principles and goals, the Postsecondary Framework identifies the multifaceted barriers that often confront Aboriginal peoples' education and training opportunities. Beyond the socio-cultural, financial, and geographic obstacles, the Postsecondary Framework alludes to the more subtle barriers for Aboriginal peoples, describing them as institutional and systemic conditions that are, often, not aligned to Aboriginal world views and traditions $(2011,9-10)$. In an effort to shed light upon some of these barriers, the Vision section of the Postsecondary Framework cites the belief in the holistic nature of education held by many Aboriginal peoples, and as a result the Ministry 
of Training, Colleges, and Universities commits itself to partner with Aboriginal leaders and communities in order to "support the revitalization of Aboriginal cultures, languages, and identities through the development and delivery of education" (12). In order to support Aboriginal learners, the Postsecondary Framework considers the issue of Aboriginal student self-identification to be "an integral component" (20) of measuring the outcomes and success of the policy, enabling the MTCU to access the relevant data necessary to determine the success of the policy initiatives. The data will also serve as a means for the MTCU to be transparent and accountable when developing an Aboriginal Postsecondary Education Performance Measures Strategy that will account for the progress of the various publiclyassisted skills development and service-delivery agencies (22-24). The Postsecondary Framework cites the necessity of measuring "improvement in demonstrated, measurable outcomes in Aboriginal post-secondary education and training as a result of ministry investments" (24). Similarly, the policy refers to the need for institutions to be responsive to the identities of Aboriginal learners by engaging Aboriginal communities in consultations towards the planning and evaluating of ministry initiatives (25-26).

\section{Discussion}

The Aboriginal Postsecondary Education and Training Policy Framework (2011) represents a commendable effort on the part of the Ministry of Training, Colleges, and Universities to develop goals, strategies, and aspirations for Aboriginal learners that, as is stated in the policy, build upon the success of the Ontario Ministry of Education's Aboriginal, Métis, and Inuit Policy Framework (2007). The Postsecondary Framework situates, to some degree, the challenges and obstacles encountered by Aboriginal learners against the backdrop of changing demographics, community consultations, and institutional capacities that will better represent Aboriginal learners' identities and worldviews. From a critical discourse analysis perspective, however, the interwoven implications of a policy discourse driven first by the language of gaps and measurement and, second, by the favourable positioning of the MTCU's support and commitment as the governing body and as a responsible bureaucracy of public money, deserves a closer examination.

\section{The Language of Gaps and Measurement}

The Postsecondary Framework identifies, as the second of its two key challenges, a focus towards "closing the educational attainment gaps between Aboriginal and nonAboriginal people" in Ontario $(2011,3)$. While this challenge might be considered at first as a central tenet of educational reform policy, particularly in light of the No Child Left Behind (2001) initiatives in the United States of America (see Porter, Polikoff, and Smithson 2009; Finn, Petrill, and Julian 2006), a more critical interrogation of the notion of "closing the educational attainment gaps" may, in fact, be masking a problematic rhetoric. More specifically, if the proverbial gap were essentially to "close," then by necessity this would imply one of three scenarios - two of which are rather dubious. The first, and most promising, of interpretations would include Aboriginal student achievement as more rapidly improving than non-Aboriginal student achievement; hence, both populations of students are improving, albeit at varying degrees. Less promising are the two other 
scenarios: one, that the educational attainment of Aboriginal learners is rising, but that the educational achievement of non-Aboriginal learners is remaining consistent and thus not improving; or, as a second scenario, that the educational attainment of Aboriginal learners is staying consistent and not improving, while the same indicators of achievement for non-Aboriginal learners are declining. In both instances, the gap would, in fact, be closing. Quite problematically, in the latter two scenarios, the language used in the phrase "closing the gap" implies an inauspicious consequential outcome between the sample populations (Aboriginal and non-Aboriginal learners) who occupy either side of the equation. One wonders if this rhetoric is more characteristic of an exclusionary policy that may be undermining the intended goals, vision, and principles of the Ministry of Training, Colleges, and Universities's Postsecondary Framework, and if, in fact, policy makers would have been better served to articulate a clearer definition of how the gap might be closed. By not doing so, the concept inherent in the policy is subject to varying interpretations.

Furthermore, while one may be so inclined to identity this implication as a paradox, it may also be a contradiction of educational ideology. The contradiction rests squarely in how the rhetoric of "closing the gap" is constructed, since the determinant of success might imply adverse outcomes for either Aboriginal or non-Aboriginal learners (as explained in the second and third scenarios). Given the Postsecondary Framework's objective to close the gap, one might assume that the non-Aboriginal learner population would be forfeiting improved outcomes. Of course, this ideological contradiction would not exist if the nonAboriginal learner population was achieving at peak performance measures-in that case, a "close in the gap" would mean that those lower-level achievers would be closing in, statistically, on the non-Aboriginal learners achieving at the highest performance level. Quite obviously, this is not the case in Ontario, making the contradiction somewhat troubling.

Consider as well a statistical comparison of the proportion of the total Aboriginal and non-Aboriginal population aged 25 to 34 who are not attending school, and who had completed post-secondary education in selected Ontario cities in 1981 and 2001 (Siggner and Costa 2005). According to the statistics, 32.1 percent of Aboriginal males completed post-secondary education in Ottawa-Hull in 1981, as compared to 32.4 percent in $2001-$ representing a 0.3 percent increase. In Toronto, 26.5 percent of Aboriginal males completed post-secondary in 1981, compared to 38.4 percent in 2001, marking an 11.9 percent improvement. In Sudbury, the numbers were 28.6 percent (1981) and 38.2 percent (2001), accounting for a 9.6 percent increase. Finally, the same statistical categories were 25 percent (1981) and 30.8 percent (2001) in Thunder Bay, indicating a 5.8 percent rise.

The increase in the percentage of Aboriginal female persons in this demographic were significantly higher. In Ottawa-Hull, 26.1 percent completed post-secondary in 1981, while 41.1 percent did the same by 2001 , pointing to a 15 percent improvement. The statistics in Toronto were nearly identical-26.2 percent (1981) and 41.3 percent (2001), representing a 15.1 percent difference. The statistical difference was most significant in Sudbury, where the numbers ranged from 10.3 percent (1981) to 33.9 percent (2001), indicating a 23.6 percent increase in the sample population. Thunder Bay also reported a rise, albeit one more comparable to Ottawa and Toronto, reporting 17.6 percent of this sample's population to have completed post-secondary education in 1981 as compared to 31.4 percent in 2001-a difference of 13.8 percent (see Table 1). 
TABLE 1: Aboriginal Population (25 to 34 Years of Age) Who Have Completed Postsecondary Education in Select Ontario Cities, in 1981 and 2001.

\begin{tabular}{|c|c|c|c|c|c|c|}
\hline \multirow[t]{2}{*}{ Ontario Cities } & \multicolumn{2}{|c|}{ Aboriginal Males } & \multirow[t]{2}{*}{ Difference } & \multicolumn{2}{|c|}{ Aboriginal Females } & \multirow[t]{2}{*}{ Difference } \\
\hline & 1981 & 2001 & & 1981 & 2001 & \\
\hline Ottawa-Hull & $32.1 \%$ & $32.4 \%$ & $+.3 \%$ & $26.1 \%$ & $41.1 \%$ & $+15 \%$ \\
\hline Toronto & $26.5 \%$ & $38.4 \%$ & $+11.9 \%$ & $26.2 \%$ & $41.3 \%$ & $+15.1 \%$ \\
\hline Sudbury & $28.6 \%$ & $38.2 \%$ & $+9.6 \%$ & $10.3 \%$ & $33.9 \%$ & $+23.6 \%$ \\
\hline Thunder Bay & $25 \%$ & $30.8 \%$ & $+5.8 \%$ & $17.6 \%$ & $31.4 \%$ & $+13.8 \%$ \\
\hline
\end{tabular}

While it is noteworthy that there were increases in the respective completion rates for Aboriginal males and females in all four Ontario cities, it is also relevant to compare these statistics with those for the same demographics in the non-Aboriginal population. In Ottawa, the number of non-Aboriginal males who had completed post-secondary education rose from 39.1 percent (1981) to 54.2 percent (2001); in Toronto, 39.1 percent of the population completed post-secondary education in 1981, as compared to 49.4 percent twenty years later. In Sudbury and Thunder Bay, the statistics were 34 percent and 40.9 percent in 1981, as compared to 48.9 percent and 44.6 percent in 2001, respectively. In terms of the non-Aboriginal female demographic, the Ottawa-Hull region posted 34.4 percent in 1981 and 55.8 percent in 2001, while in Toronto the percentage of the female non-Aboriginal population who completed post-secondary in 1981 was 32.6 percent, as compared to 52.2 percent in 2001. Similar positive differences were recorded in Sudbury and Thunder Bay, with 28.3 percent and 34.9 percent in 1981, and 53 percent and 53.3 percent in 2001.

The most telling statistics in the above comparisons rest in the differences between these populations spanning the twenty years between 1981 and 2001. Consider that, in all four of the cities under comparison, there was an increased percentage of Aboriginal males and females (25-34 years old) who completed post-secondary education; yet, and most significantly, the increase in percentage points from 1981 to 2001 of the non-Aboriginal male and female population, in all but two cases, was higher than the Aboriginal population (the two exceptions being a comparison of Aboriginal and non-Aboriginal males in Toronto and Thunder Bay, where the percentage of Aboriginal males only slightly outweighed the non-Aboriginal male sample by two and one percent respectively). In Ottawa, a significant 15 percent difference exists between the two male populations and a 4 percent difference in Sudbury. As for the female demographic, the percentage difference for non-Aboriginal females was higher in all four Ontario cities, indicative of a 6 percent difference in OttawaHull, 5 percent in Toronto, 2 percent in Sudbury, and a 5 percent difference in Thunder Bay (see Table 2).

TABLE 2: Non-Aboriginal (25 to 34 Years of Age) Who Have Completed Post-secondary Education in Select Ontario Cities, in 1981 and 2001.

\begin{tabular}{|l|l|l|l|l|l|l|}
\hline \multirow{2}{*}{ Ontario Cities } & \multicolumn{2}{|l|}{ Non-Aboriginal Males } & \multirow{2}{*}{ Difference } & \multicolumn{2}{|l|}{ Non-Aboriginal Females } & Difference \\
\cline { 2 - 3 } \cline { 6 - 7 } & 1981 & 2001 & & 1981 & 2001 & \\
\hline Ottawa-Hull & $39.1 \%$ & $54.2 \%$ & $+15.1 \%$ & $34.4 \%$ & $55.8 \%$ & $+21.4 \%$ \\
\hline Toronto & $39.1 \%$ & $49.4 \%$ & $+10.3 \%$ & $32.6 \%$ & $52.2 \%$ & $+19.6 \%$ \\
\hline Sudbury & $34 \%$ & $48.9 \%$ & $+14.9 \%$ & $28.3 \%$ & $53 \%$ & $+24.7 \%$ \\
\hline Thunder Bay & $40.9 \%$ & $44.6 \%$ & $+3.7 \%$ & $34.9 \%$ & $53.3 \%$ & $+18.4 \%$ \\
\hline
\end{tabular}


These and other statistics may be useful in questioning if the rhetoric of "closing gaps" is a politically worrisome notion. As the aforementioned statistics attest, there has been an increase in the number of Aboriginal males and females in select Ontario cities who have completed post-secondary education between 1981 and 2001; nonetheless, the proverbial gap has not closed. Essentially, in all but two instances, the gap has widened. This statistical examination serves to illustrate how the rhetoric of "closing the gap" for Aboriginal learners, as it is presented throughout the Postsecondary Framework, is not only contestable but, potentially, profoundly subversive. In view of the policy context under examination, the 2011 Postsecondary Framework has its foundations in the 1991 Ontario Aboriginal Postsecondary Education and Training Strategy that (as previously stated) identified the need to increase the enrolment and graduation rates of Aboriginal students in post-secondary schools. While there is no doubt that the 1991 policy contributed to positive outcomes, it is noteworthy that the 1996 Royal Commission on Aboriginal Peoples Report cited (five years into the run of the 1991 Ontario policy) that representatives from Aboriginal communities commented consistently on the fundamental need for improved post-secondary and training opportunities for Aboriginal students. Consider as well that, as recently as 2005, Aboriginal student enrolment in higher education still lagged behind. Further, Rae's Postsecondary Review: Higher Expectations for Higher Education concluded that retention and completion rates for Aboriginal students in Ontario needed to be addressed, as did accumulating "good data about Aboriginal participation and completion" $(2005,65)$.

In a similar light, there are issues related to measurement strewn throughout the Postsecondary Framework that invite further thought. Among the goals of the Framework is to achieve "measurable changes in Aboriginal post-secondary education and training in Ontario" (4). The policy accounts for the difficulties identified in the literature that Aboriginal students often deal with in transitioning to post-secondary education, including adjusting to different social and academic contexts (Rendon, Jalomo, and Nora 2000), living circumstances, and realities (Braxton et al. 2004), the lack of culturally inclusive teaching and learning practices (Malin1998), and the often lower expectations that instructors have for Aboriginal students in comparison to non-Aboriginal learners (Hart 2002; PirbhaiIllich 2011). The literature further attests to the colonial paradigms of learning that, in many instances, lead to Aboriginal students' resistance towards education (Silver and Mallott 2002), which contributes significantly, in turn, to potential feelings of alienation and negative self-worth as learners (Waller et al., 2002). In this context, the Postsecondary Framework commits to "engender[ing] more positive outcomes for Aboriginal learners" (2011, 5) by establishing what the Ministry of Training, Colleges, and Universities describes as "reliable data systems ... so progress and achievement in Aboriginal education in Ontario can be accurately tracked" (10). While it is difficult to argue against the need to accurately track progress and achievement, the following description of the Postsecondary Framework's purpose invites further consideration: "The policy framework is intended to be used to influence attitudes and approaches of the postsecondary education and training sectors so that these sectors become increasingly aware of, and responsive to, the unique needs, circumstances, perspectives, and knowledge systems of a wide spectrum of Aboriginal learners" (11). Note, in the above statement of purpose, how the language is 
fixed on concepts related to the affective domain: the focus rests on influencing attitudes, increasing awareness, and being responsive to the array of socio-political, socio-cultural, historic, and epistemic realities of Aboriginal learners. Not only is the intent of these statements significant and far from modest, but the question that begs to be asked is how exactly the MTCU will fulfill its mandate to measure and accurately track changes in attitudes, approaches, and awareness at the institutional and service-delivery levels.

To put it another way, how does one measure, using what the policy describes as reliable data systems (presumably in response to the 2005 Postsecondary Review: Higher Expectations for Higher Education that called for good data), an institution's heightened awareness of Aboriginal history and Aboriginal learners' contemporary experiences in educational and training spaces? How can it be determined that institutional and individual attitudes and approaches to Aboriginal learners have been positively influenced? While the intent to shape practice in order to heighten what the Postsecondary Framework refers to as "awareness of the needs and perspectives of Aboriginal learners" (14) is momentous, the ambiguous nature of quantifying affective concepts may essentially undermine the principle of the intent, rendering the notion rather token and superficial. The Postsecondary Framework identifies the need to develop "more holistic measures of success" (19), yet it is not clear how such measures will transform into the "reliable and relevant quantitative and qualitative date [deemed by the Ministry of Training, Colleges, and Universities as] critical in determining how well programs and services are serving Aboriginal learners" (20).

\section{Strategic Discourse}

The Vision of the 2011 Postsecondary Framework includes key elements that underpin Aboriginal learners' experiences in educational and training institutions. The policy alludes to the significance of representing Aboriginal peoples' unique identities as they enter into, and continue towards, achieving post-secondary aspirations. The intent of these efforts is praiseworthy. The respective vision, goals, and principles of the Postsecondary Framework cannot, however, be considered in isolation, apart from the strategic discourse used throughout the document that positions the Ministry of Training, Colleges, and Universities quite favourably as the supportive and committed governing body in Ontario. This is not meant to criticize the MTCU for the language chosen for inclusion in the Policy Framework, but to explore, through critical discourse analysis, the potentially vague spaces between policy intent and practical implications.

To begin, the adjective "renewed" is used in the Introduction $(2011,4)$, twice in the Executive Summary (5), and in the description of Context (10). In the Introduction, "renewed" describes the Ministry of Training, Colleges, and Universities' approach to Aboriginal students' aspirations towards post-secondary education and the respective measures for change. The implication is that such a commitment to Aboriginal learners is not a new dimension of the MTCU's policy, but rather a transformed attempt to improve MTCU services. In the Executive Summary, it is stated that the Postsecondary Framework, in fact, "signals a renewed commitment" on the part of the MTCU "to support" Aboriginal learners. According to the document, the policy "provides a vehicle for reflecting on the successes of the past and building upon the solid foundation" (5) of individuals who 
have contributed to Aboriginal peoples' access to post-secondary options. The discourse is driven by connotations that embed the MTCU's commitment to Aboriginal learners and their willingness to support Aboriginal peoples' development while positioning the impression of benevolent supporter squarely in successes of the past. Notably, the Ontario Ministry of Education's Aboriginal, Métis and Inuit Policy Framework (2007) makes a similar commitment to supporting Aboriginal students and communities in K-12 publicly funded schools. The OME's 2007 policy, like the Postsecondary Framework (2011), employs a discourse that positions the governing body as being most willing to offer their support and concentrated attention to Aboriginal students (Cherubini 2010).

Conversely, the policy presented in the Postsecondary Framework signifies the Ministry of Training, Colleges, and Universities' "renewed action" $(2011,5)$ to ensure "more positive outcomes" (5) for Aboriginal learners. The Executive Summary of the policy unfolds impressions that are uncategorically strong and favourable of the MTCU's revamped endeavours to sustain Aboriginal learners' experiences further. Central to this impression is the provincial government's interest in wanting to counter the erosion of Aboriginal learners' linguistic and cultural traditions, which the literature has identified as having had adverse consequences on Aboriginal students, their families, and communities (Hare and Anderson 2010; Hare and Barman 2000). The collective actions described in the policy lends to interpretations of a governing body that continues to lobby vigorously for Aboriginal learners. The discourse suggests a high degree of sensitivity and action on the part of the MTCU to successfully integrate Aboriginal learners' experiences with postsecondary institutions and training facilities. Interestingly, Rae's Postsecondary Review on Higher Education (2005) cited that the Native Education Council that was created by the 1991 Aboriginal Education and Training Strategy to advise the Minister of Education in Ontario on all matters related to Aboriginal post-secondary education was eliminated in 1996. How this factors into the Ministry's self-declared "renewed action" and "commitment" to Aboriginal education is left for the public to decide.

Similarly, the Postsecondary Framework includes a declarative statement that the challenges that often confront Aboriginal learners in post-secondary settings "require focused and sustained action" $(2011,8)$ on the part of the Ministry of Training, Colleges, and Universities. The discourse depicts governmental response in a rhetoric that is clear and precise. Action, in light of the aforementioned challenges, promises to be defined, clear-cut, and continuous. In this way, the MTCU's consistent references to "a renewed commitment" and "support" (10) of Aboriginal learners are woven, as a compelling theme of sorts, throughout the text of the document. As the policy unfolds its explanation of purpose, it presents the Framework as "the next step" (11) of Ontario's commitment to Aboriginal education, clearly implying their continual efforts in this regard. One might be left to question, though, the specific success of previous steps in provincial policy.

Just as the strategic discourse situates the Ministry of Training, Colleges, and Universities favourably, so too does the language of the Postsecondary Framework, which denotes the ministry as a responsible guardian of public money. As the policy document describes the various gaps in educational attainment and achievement, as well as some of the historically rooted causes for Aboriginal learners' disengagement from formal education, the neo-liberal rhetoric of labour market values justifies the existence of the 
policy for the tax-paying public by citing the detrimental "costs of not having a skilled and educated population that is able to participate in the labour market" (5). The rhetoric subtly reinforces that a citizenry with advanced education is generally less reliant upon social services and assistance (National Center for Public Policy and Higher Education [NCPPHE] 2004; Barrow and Rouse 2005; Barton 2008). The fact that youth homelessness (Sider 2005), high rates of childhood poverty (Native Women's Association of Canada 2007), unemployment (Luffman and Sussman 2007), and incarceration (Brown et al. 2005) have an impact on Aboriginal peoples in particular, serves to impart the necessity to the general public that investing in the initiatives of the Postsecondary Framework makes good sense.

In addition, the Context of the Postsecondary Framework makes clear that the greatest proportion of Canadian Aboriginal peoples reside in Ontario, and that from 1995 to 2005 the Aboriginal population increased almost six times faster than the non-Aboriginal population. The policy identifies the projected 16 percent increase in the Aboriginal population in Ontario by 2017, implying here too that monies invested in Aboriginal education and training are well spent, since a more educated, trained, and growing population will be less reliant on public funds. The context of the policy document concludes by quite explicitly repeating, and hence reminding the public, of "the costs of not having a skilled and educated population that is able to actively participate in the labour market" $(2011,10)$. By sheer implication, one wonders if this policy discourse is indirectly reinforcing the same "deficit lens" perception that has historically existed in government publications and various works of scholarship related to Aboriginal students' lower academic achievement and higher rates of absenteeism, and if it further compounds this perception in the discourse of the projected growth of the Aboriginal populations in Ontario (Cherubini 2010; Redefining Success 2007).

It may be relevant to juxtapose the rhetoric of the Ontario Ministry of Education's Policy Framework (2007) in support of this analysis. For example, the OME Policy Framework, published four years earlier, also employed the rhetoric of "labour markets" as the measure to evaluate a normative standard of living for all Ontarians. However, such standards are reflective of Eurocentric understandings of post-colonial peoples. The same criticism that was applicable to the $2007 \mathrm{OME}$ policy document may have currency in a consideration of the 2011 Postsecondary Framework:

The rhetorical constructions within the Policy Framework [2007] seem to accentuate the Ontario Ministry of Education's status as provider of the necessary skills and services that will redeem the Aboriginal population and enhance their potential to more meaningfully contribute to a capitalist and market-driven economy - an intention that may not necessarily be too strikingly different from the assimilationist colonial practices of years gone by (Cherubini 2010).

This discourse illustrates a prudent and responsible bureaucracy investing in Aboriginal educational initiatives at present in order to avoid disproportionate dependencies on social services by a swelling demographic population in Ontario, and recasts the necessity for Ontario taxpayers to invest in the Postsecondary Framework. The policy's long-term vision transforms the gaps and dependencies identified previously in the document as a means to "strengthen the social fabric for all Ontarians" and not just Aboriginal learners $(2011,12)$. 
It is interesting how the language of labour markets, characteristic of neo-liberal ideologies, transitions to an implication that advancing the economic conditions of Aboriginal learners (and, hence, the next generation of the Aboriginal population) will benefit the public at large. In a similar vein, the policy's principle of excellence and accountability cites economic development in the same sentence as social and cultural development (13). The terms appear to be synonymous with one another in the Ministry of Training, Colleges, and Universities' efforts to construct purposeful and sustained action towards Aboriginal learners in post-secondary environments. The promise, according to the Postsecondary Framework, is to "benefit all people in Ontario" (14), and to "enrich the education of all Ontarians" (15). The consistent rhetoric of the collective-the entire taxpaying publicimpresses the relevancy of the policy far more broadly.

\section{Conclusion}

Both the Ontario Ministry of Education and the Ministry of Training, Colleges, and Universities, as provincial governing bodies, have made recent investments in policy related to Aboriginal education and training. The MTCU's Aboriginal Postsecondary Education and Training Policy Framework identifies the past significant barriers that have prevented many Aboriginal learners from successfully transitioning to their postsecondary aspirations and represents the Ontario government's self-declared commitment to Aboriginal learners, their communities, and the tax-paying public, as well as the intent to close the educational gaps between Aboriginal and non-Aboriginal learners in Ontario.

The objectives of this discourse analysis were to bring to light what might be considered as the troubling language used throughout the policy that describes the notion of closing achievement gaps and, in a related manner, to issues of measurement. Moreover, the analysis focuses upon the strategic discourse in the language of the policy that favourably positions the governing body as a supportive, committed, and responsible manager of public money. Ultimately, the analysis is meant to explore the often ambiguous spaces between policy intent and practical implications. 


\section{Bibliography}

Barrow, L., C.E. Rouse. 2005. “Does College Still Pay?” Economists' Voice 4: 1-9. http:// dx.doi.org/10.2202/1553-3832.1097.

Barton, P.E. 2008. "How many college graduates does the U.S. labor force really need?" Change 40: 16-21. http://dx.doi.org/10.3200/CHNG.40.1.16-21.

Braxton, J.M., A.S. Hirschy, and S.A. McClendon. 2004. Understanding and Reducing College Student Departure. San Francisco: Jossey Bass.

Brown, J., N. Higgs, S. Winger, C. Miller, and L. Morrissette. 2005. "Challenges Faced by Aboriginal Youth in the Inner City." Canadian Journal of Urban Research 14 (1): 81-106.

Carnevale, A.P., and D.M. Derochers. 2003. Standards for What? The Economic Roots of K-16 Reform. Princeton, NJ: Educational Testing Service.

Cherubini, L. 2010. "An Analysis of Ontario Aboriginal Education Policy: Critical and Interpretive Perspectives.” McGill Journal of Education 45 (1): 9-26.

Fairclough, N. 1992. Discourse and Social Change. London: Polity Press.

- - - 2001. Language and Power. London: Longman Press.

-_- 2003. Analyzing Discourse: Textual Analysis for Social Research. London: Routledge.

Finn, C.E., M.J. Petrilli, and L. Julian. 2006. The State of State Standards 2006. Washington, DC: Thomas B. Fordham Foundation.

Grove, S. 2005. “The Equality and Liberty Rights of the Destitute: A Canadian Charter Case Example." International Journal on Minority and Group Rights 12: 43-61.

Grubb, W.N. 2002. "Learning and Earning in the Middle, Part I: National Studies of Prebaccalaureate Education." Economics of Education Review 21: 299-321. http:// dx.doi.org/10.1016/S0272-7757(01)00042-5.

Hare, J., and J. Anderson. 2010. “Transitions to Early Childhood Education and Care for Indigenous Children and Families in Canada: Historical and Social Realities." Australian Journal of Early Childhood 35 (2): 19-27.

Hare, J., and J. Barman. 2000. “Aboriginal Education: Is There a Way Ahead?” In Visions of the Heart: Canadian Aboriginal Issues, 2nd ed., ed. D. Long and O. Dickson, 331-59. Toronto: Harcourt Brace.

Hart, M.A. 2002. Seeking Mino-Pimatisiwin: An Aboriginal Approach to Helping. Halifax: Fernwood.

Luffman, J., and D. Sussman. 2007. “The Aboriginal Labour Force in Western Canada.” Perspectives on Labour and Income 8 (1). Statistics Canada Catalogue no. 75-001XIE. 
Malin, M. 1998. “They Listen and They’ve Got Respect. Culture and Pedagogy.” In Perspectives on Aboriginal and Torres Strait Islander Education, ed. G. Partington, 245-73. Katoomba, AU: Social Science Press.

McIntyre, M., K. Francis, and Y. Chapman. 2012. "Critical Discourse Analysis: Understanding Change in Maternity Services." International Journal of Nursing Practice (18): 36-43.

Ministry of Training, Colleges and Universities. 2011. Aboriginal Postsecondary Education and Training Policy Framework. Toronto: Queen's Printer for Ontario.

National Centre for Public Policy and Higher Education (NCPPHE). 2004. The Educational Pipeline: Big Investment, Big Returns. San Jose, CA.

Native Women's Association of Canada. 2007. Aboriginal Women and Homelessness: An Issue Paper. Prepared for the National Aboriginal Women's Summit in Corner Brook, NL. Ottawa: Native Women's Association of Canada.

Norris, M. J., and S. Clatworthy. 2003. "Aboriginal Mobility and Migration within Urban Canada: Outcomes, Factors and Implications." In Not Strangers in These Parts: Urban Aboriginal People, ed. D. Newhouse and E. Peters, 51-78. Ottawa: Policy Research Initiative.

Ontario Ministry of Education (OME). 1991. Ontario's Aboriginal Postsecondary Education and Training Strategy. Toronto: Queen's Printer for Ontario.

-_- 2007. Ontario Aboriginal, Métis, and Inuit Education Policy Framework. Toronto: Aboriginal Education Office.

Pirbhai-Illich, F. 2010-2011. "Aboriginal Students Engaging and Struggling with Critical Multiliteracies." Journal of Adolescent \& Adult Literacy 54 (4) 257-66.

Porter, A. C., M. Solikoff, and J. Smithson. 2009. "Is there a de facto national intended curriculum? Evidence from state content standards?" Educational Evaluation and Policy Analysis 31 (3): 238-68. http://dx.doi.org/10.3102/0162373709336465.

Rae, B. 2005. Ontario: A Leader in Learning. Toronto: Queen's Printer for Ontario.

Canadian Council on Learning. 2007. Redefining how success is measured in Aboriginals, Inuit and Métis Learning. 2007. Report on Learning in Canada. Ottawa. Accessed May 23, 2012. www.ccl-cca.ca.

Rendón, L. I., R.E. Jalomo, and A. Nora. 2000. “Theoretical Considerations in the Study of Minority Student Retention in Higher Education." In Reworking the Departure Puzzle, ed. J.M. Braxton, 127-56. Nashville, TN: Vanderbilt University Press.

Royal Commission on Aboriginal Peoples. 1996. Report of the Royal Commission on Aboriginal Peoples. Ottawa: Ministry of Supply and Services.

Sider, D. 2005. A Sociological Analysis of Root Causes of Aboriginal Homelessness in Sioux Lookout, Ontario. Toronto: The Canadian Race Relations Foundation.

Siggner, A. J., and R. Costa. 2005. Trends and Conditions in Census Metropolitan Areas: Aboriginal Conditions in Census Metropolitan Areas, 1981-2001. Ottawa: Statistics Canada. 
Silver, J., and K. Mallett, with J. Greene and F. Simard. 2002. Aboriginal Education in Winnipeg Inner City High Schools. Winnipeg: Canadian Centre for Policy Alternatives-Manitoba.

Smith, J.L. 2007. “Critical Discourse Analysis for Nursing Research.” Nursing Inquiry 14: 60-70. http://dx.doi.org/10.1111/j.1440-1800.2007.00355.x.

Thompson, J.B. 1994. Studies in the Theory of Ideology. Cambridge: Polity Press.

U.S. Congress. Senate. 2001. No Child Left Behind Act. 107th Cong. Pub. L. No. 107-110, $\$$ 115 , Stat. 1425

Valentine, J.C., A.S. Hirschy, C.D. Bremer, W. Novillo, M. Castellano, and A. Banister. 2011. "Keeping at-risk students in school: A systematic review of college retention programs." Educational Evaluation and Policy Analysis 33 (2): 214-34. http:// dx.doi.org/10.3102/0162373711398126.

Waller, M.A., S.K. Okamoto, A.A. Hankerson, T. Hibbeler, P. Hibbeler, P. McIntyre, and Roland McAllen-Walker. 2002. "The Hoop of Learning: A Holistic, Multisystemic Model for Facilitating Educational Resilience among Indigenous Students." Journal of Sociology \& Social Welfare 29 (1): 97-116. 